\title{
Evaluation of Marine Wood Boring Organism's Attack on Wood Materials in the Black Sea Coastal Region
}

\begin{abstract}
Ahmet Can,* and Hüseyin Sivrikaya
Wood has been used in many areas including the marine environment due to its important properties. However, marine borers cause damage that shortens the service life of wooden materials. Marine borers have a wide distribution and employ different attack mechanisms depending on the geographical region. In this study, wood samples prepared from the Pinus sylvestris $L$. species were subjected to marine exposure for seven months in the Eastern, Central, and Western Black Sea Regions. Results showed that Teredo navalis marine borer was observed in all three regions. The $\mathrm{N}, \mathrm{Mg}, \mathrm{S}, \mathrm{Cl}, \mathrm{Ca}, \mathrm{Fe}, \mathrm{Zn}$, and $\mathrm{Pb}$ content of the samples noticeable increased after the marine trial. According to Fourier transform infrared analysis, carbohydrate content of the samples decreased noticeable, while lignin content increased.
\end{abstract}

Keywords: Cellulose content; Chemical composition of wood; Marine environment; Teredo navalis

Contact information: Department of Forest Industrial Engineering, Faculty of Forestry, Bartin University, Bartin, Turkey; *Corresponding author: acan@bartin.edu.tr

\section{INTRODUCTION}

The destruction of wood materials by marine borers and the economic loss due to this damage have led to an increase in the use of concrete and steel. However, the use of wood is preferred because of its performance and low specific gravity compared to other constructional materials (concrete, steel, etc.) in addition to its low greenhouse gas effect (Borges et al. 2003; Bergman et al. 2014). Wood has been used in maritime construction due to its mechanical strength and elasticity, low energy production costs, and renewability (Cragg 1996). Moreover, wood is known to be more resistant to seawater than steel and concrete (Williams et al. 2005). However, marine wood borers, molluscs, and crustaceans attack wood materials in a marine environment.

There are many species of organisms that attach themselves to the surface of wood materials submerged in seawater and cause the wood to deteriorate. These organisms erode wood and shorten its service life. Marine borers that damage wood in the sea are classified as molluscs and crustaceans. The presence of any wood boring organism in a particular area is largely restricted by the temperature, salinity, contamination, and the availability of suitable host material of the seawater. In addition, the depth, oxygen content, turbidity, amount of the sea water, and the suspended organic matter also affect the spread of the borers (Cragg et al. 1999; Perçin 2007; Eriksen et al. 2014). Borges et al. (2014) reported that Teredo navalis and Nototeredo norvagica showed the widest distribution in European waters, and that $T$. navalis was one of the few species considered to present the greatest hazard to wooden maritime structures in the European coastal areas. In the past, some studies were conducted on the wood-destroying marine borers in Turkish coastal waters (Sivrikaya et al. 2008, 2009, 2012; Sen et al. 2010; Borges 2014). According to an earlier 
study, Teredo navalis, Limnoria tripunctata, and Chelura terebrans were identified in the Western Black Sea Region (Amasra) at different periods from 1968 to 1969 (Pinar 1997). Bobat (1994) found only one species, T. navalis, in an Eastern Black Sea site (Trabzon), whereas Sen et al. (2010), in addition to T. navalis, also reported the species of Lyrodus pedicellatus and Nototeredo norvagica in Trabzon and L. pedicellatus of the Western Black Sea Region (Ereğli).

The aim of this research was to determine the changes in the properties of Scots pine wood caused by marine borers through submergence of wood samples in the Eastern, Central, and Western Black Sea Regions for a period of seven months, the results were compared with the properties of twin control samples that had not been submerged in seawater. A number of aspects were investigated, including changes in physical appearance, X-ray imaging, the $\mathrm{pH}$ of the wood, and the mineral content determined via inductively coupled plasma atomic emission spectroscopy (ICP-AES). In addition, the cellulose, hemicellulose, and lignin content were determined via attenuated total reflectionFourier-transform infrared (ATR-FTIR) analysis.

\section{EXPERIMENTAL}

\section{Materials}

In this study, Scots pine panels (Kartal Ahşap, Bartin, Turkey) were prepared from sapwood blocks at air-dried weight. Five replicates were used for each variation. The samples were free of knots and insect and fungal attack. The test samples were prepared by cutting tangentially in dimensions of $25 \times 75 \times 200 \mathrm{~mm}^{3}$ according to TS EN 275 (2000).

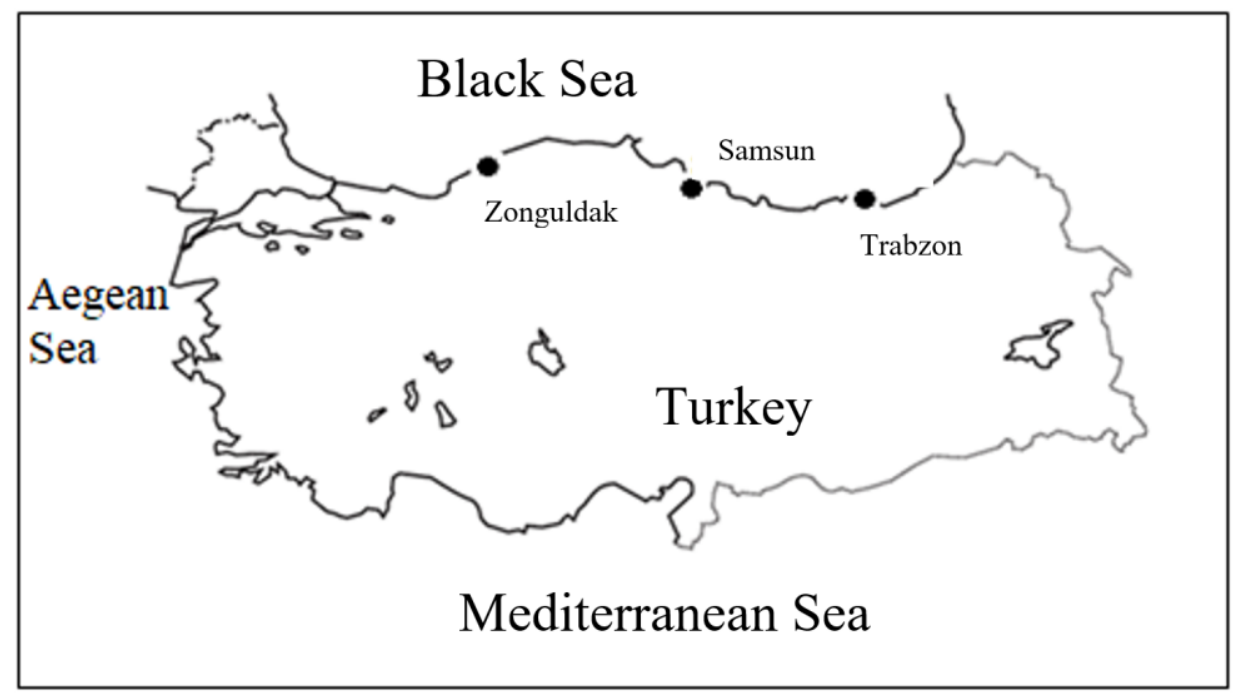

Fig. 1. Test sites chosen for the study

The test panels were attached to a polypropylene rope with a stone weight to hold them underwater. They were suspended vertically $6 \mathrm{~m}$ from sea surface when in low tide, with the larger dimension of the panels oriented horizontally. Literature studies have stated that the impregnated control samples are destroyed in a short time and one summer period is sufficient for testing (Sivrikaya et al. 2008, 2009). Therefore, for this study, the samples 
were left in seawater for seven months. According to the TS EN 275 (2000) standard (CEN), if the attack destroyed more than $50 \%$ of the tunnels ratio created by marine borers in the wood panel, it is rated as a 'number 4'. Earlier studies in the Turkish waters showed that the exposition of wood panels in the marine environment for one summer season is sufficient for the destroyed attack experiment (Sivrikaya et al. 2008, 2009, 2012). The test sites (Fig. 1) were selected to involve the Black Sea. The test panels were deployed in the coastal sites of Trabzon $\left(41^{\circ} 00^{\prime} 27.5^{\prime \prime} \mathrm{N}, 39^{\circ} 44^{\prime} 15.7^{\prime \prime E}\right)$ in the Eastern, Samsun $\left(41^{\circ} 18^{\prime} 29.9^{\prime \prime} \mathrm{N}, 36^{\circ} 20^{\prime} 27.9^{\prime \prime} \mathrm{E}\right)$ in the Central, and Zonguldak $\left(41^{\circ} 27^{\prime} 19.5^{\prime \prime} \mathrm{N}, 31^{\circ} 47^{\prime} 12.9^{\prime \prime} \mathrm{E}\right)$ in the Western Black Sea Regions in Turkey. The average seawater temperature in the Black Sea was $15.2^{\circ} \mathrm{C}$ and $\mathrm{pH}$ values were measured as 9.06 for Trabzon, 8.97 for Samsun, and 10.02 for Zonguldak during test (from Sep. 2016 to April 2017). Salinity of the seawater in the Black Sea has been recorded as 18\%o (Muhiddin et al. 2002).

\section{Methods}

At the end of the 7-month test period, the test samples were removed from the sea to evaluate the marine boring activity and identify the wood-boring species. Four of five test panels were analyzed via destructive methods and the fifth one was retained for nondestructive X-ray testing. The panels were split open to reveal the extent of interior damage and to extract the wood boring organisms. The severity of attack was visually apparent in cases where whole shipworms were removed from the panels, while in others, only pallets and shells were found (Fig. 2). The teredinid were preserved in $70 \%$ ethanol and identified using the pellet (Turner 1971) and descriptions (Turner 1966) of Turner.

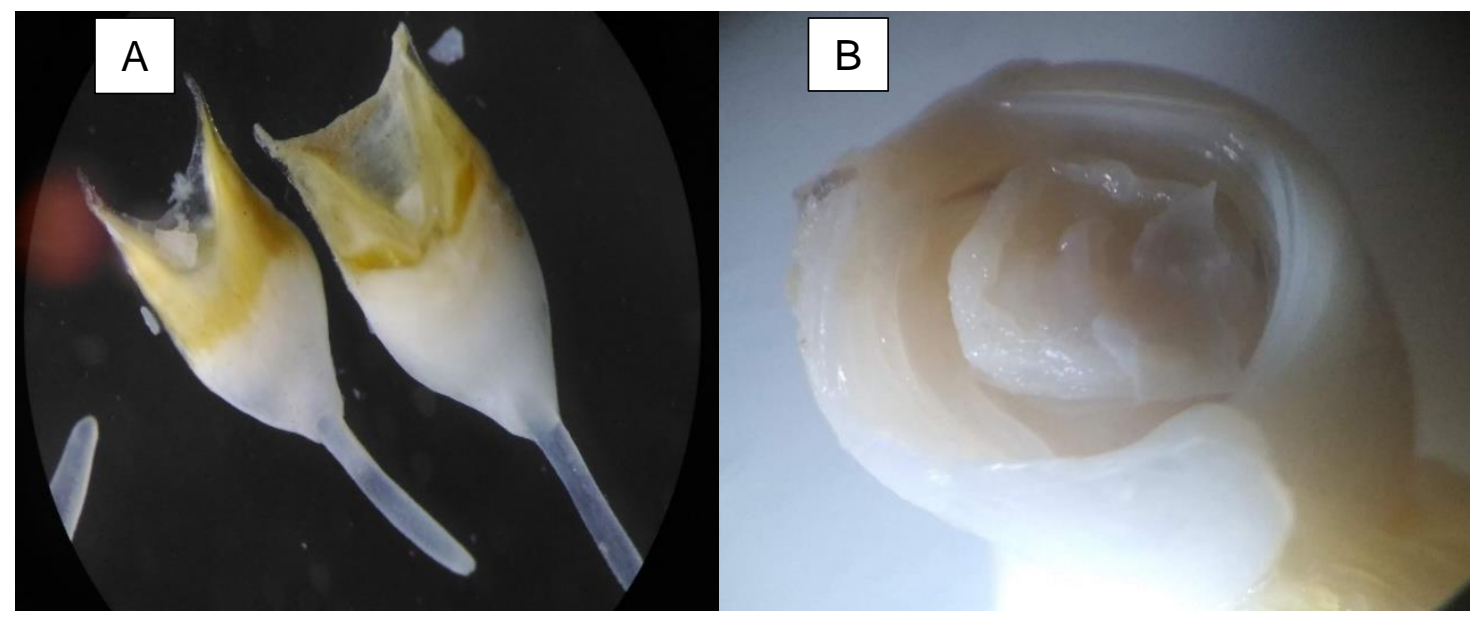

Fig. 2. Teredo navalis: $(A)$ pallets and $(B)$ shell valves

Wood samples used for $\mathrm{pH}$ measurement were prepared according to TAPPI standard TAPPI Tm-45 (1992). The air-dried samples representing each test group were screened in 40- and 60-mesh sieves after grinding in a Wiley mill, and the material remaining in the 60-mesh sieve was used for $\mathrm{pH}$ measurement. Approximately $5 \mathrm{~g}$ of wood sample from each test group were placed in an Erlenmeyer flask containing $150 \mathrm{~mL}$ of distilled water and shaken mechanically for $24 \mathrm{~h}$. At the end of the period, the $\mathrm{pH}$ was measured by water filtration. 
The quantity of the typical elements of seawater (N, P, K, Ca, $\mathrm{Mg}, \mathrm{Na}, \mathrm{Cl}, \mathrm{S}, \mathrm{Fe}$, $\mathrm{Mn}, \mathrm{Zn}, \mathrm{Cu}, \mathrm{B}, \mathrm{Cd}, \mathrm{Pb}$, and $\mathrm{Al}$ ) found in the pine wood samples prior to and after submersion in the test sites was determined by ICP-AES (ICP OES; Spectro Genesis, Kleve, Germany). This analysis investigated how the seawater changed the mineral content of the wood, i.e., to reveal the mineral content of the wood samples exposed to seawater in the different regions, because it is known that mineral substances in seawater have an effect on the life of marine organisms. Sample preparation was completed according to AWPA standard AWPA A7 (1993). Wood samples were ground in a Wiley mill (IKA, Staufen, Germany) to a sieve size of $0.2 \mathrm{~mm}$ and oven dried at $103 \pm 2{ }^{\circ} \mathrm{C}$. A total of $1 \mathrm{~g}$ of the ground wood was weighed to the nearest $0.01 \mathrm{~g}$ and placed in a $100-\mathrm{mL}$ flask. Nitric acid (65\%) was then added to the flask, which was placed on a hot plate. After the formation of brown vapor, hydrogen peroxide $(30 \%)$ was added dropwise to form a clear solution. After cooling, the contents in the flask were filtered through Whatman \#4 filter paper (Merck, Taufkirchen, Germany) and diluted with distilled water for measurement.

The X-ray imaging was performed using a Siemens AXIOM Iconos R200 system (Siemens Medical Solutions, Malvern, PA, USA) under 85 to $90 \mathrm{kV}$ and 10.4 to $11.9 \mathrm{~mA}$, for which a focal distance of $150 \mathrm{~cm}$ was used. The photographs were taken from the same side before and after the experiment without being dried to enable comparison. The tunnel area was estimated from the X-ray images, and the rating system, based on TS EN 275 (2000), was employed to score the severity of the attack: "0", no attacks present; "1", tunnel area is less than $15 \%$ of the wooden object seen on the image; " 2 ", tunnel area is 15 to $25 \%$; " 3 ", tunnel area is 25 to $50 \%$; and " 4 ", tunnel area is more than $50 \%$. Therefore, the results were qualitative estimations from a visual inspection of the images as per TS EN 275 (2000).

The ATR-FTIR analysis was conducted using a Shimadzu IRA Affinity-1 spectrometer (Shimadzu Corp., Beijing, China) equipped with a single reflection ATR pike MIRacle sampling accessory (MIRacle Single Reflection ATR accessory, Beijing, China). Samples for the ATR-FTIR analysis were prepared by grinding in a Wiley mill to a mesh size of $0.2 \mathrm{~mm}$. Four accumulated spectra were collected in the wavenumber region of 700 to $4000 \mathrm{~cm}^{-1}$, with a spectral resolution of $4 \mathrm{~cm}^{-1}$.

\section{RESULTS AND DISCUSSIONS}

\section{Visual Results}

After the 7-month trial, the marine wood borer species Teredo navalis was identified in all three test sites of Trabzon, Samsun, and Zonguldak, located along the Black Sea coast. This finding demonstrated that the species of wood boring organisms did not differ in the Eastern, Central, or Western Black Sea Region locations (Fig. 3). Some researchers also conducted similar experiments in different test sites along the Black Sea in the past (Sivrikaya et al. 2008; Sivrikaya et al. 2009). In 1968, P1nar (1997) reported higher T. navalis activity in Amasra after 12-month exposure. At the same test site, heavy attack on Scots pine samples was mentioned by Sivrikaya et al. (2012, 2016). In the present study, heavy teredinid attack was shown in the Scots pine samples and at the end of seven months, the samples from the Trabzon and Samsun test sites were brittle, while the samples from Zonguldak were slightly firmer (Fig. 3). All samples were rated as "4" because more than $50 \%$ of each panel had been bored by marine organisms. 


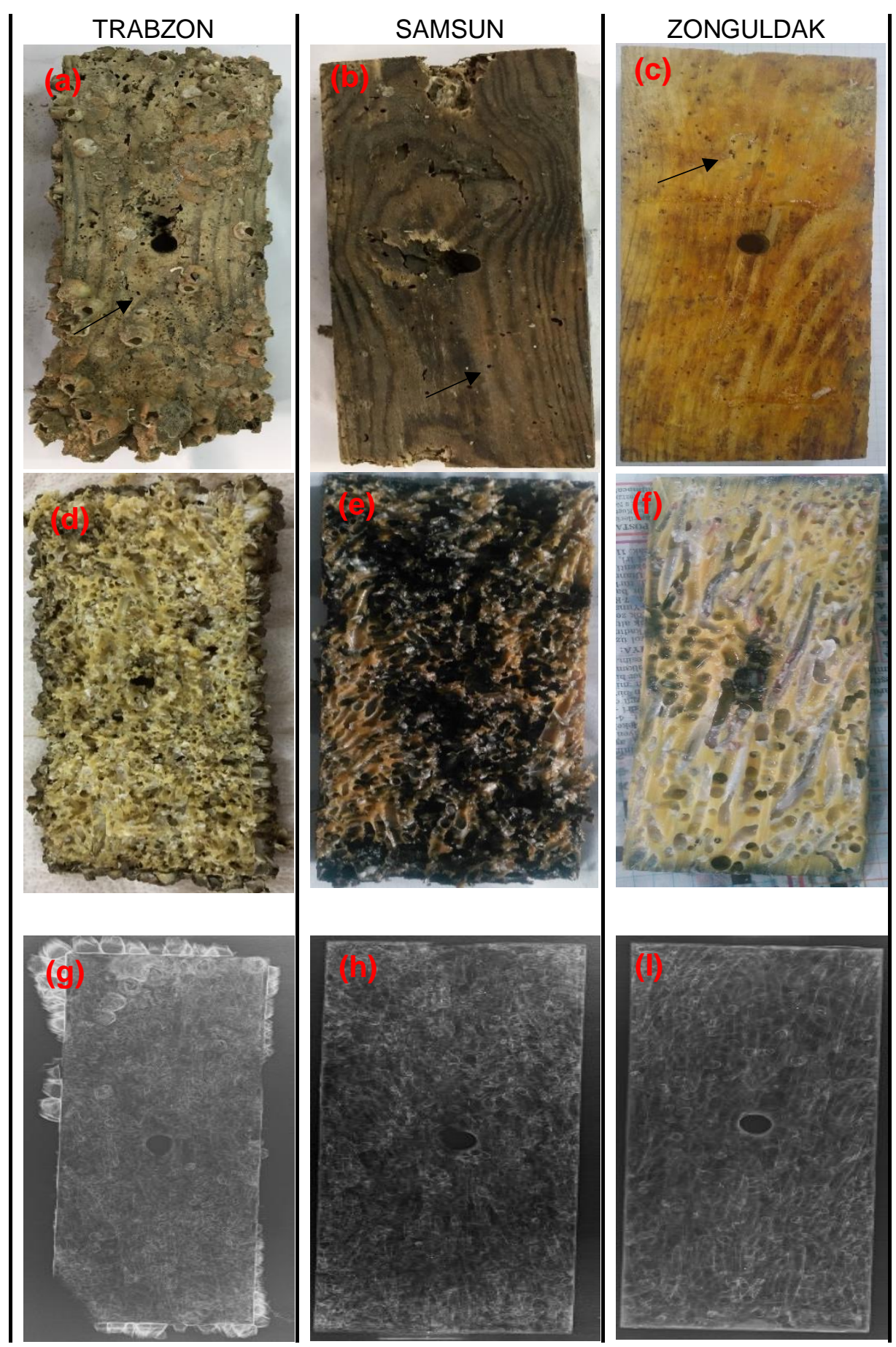

Fig. 3. Wood panels attacked by T. navalis; external image of the sample in Trabzon (a), in Samsun (b) and in Zonguldak (c), interior image in Trabzon (d), in Samsun (e) and in Zonguldak (f), X-ray images in Trabzon (g), in Samsun (h) and in Zonguldak (I)

Different species have been observed in previous studies (P1nar 1997; Sivrikaya et al. 2012, 2016). However, in this study only the T. navalis species was found in all three regions. It is conjectured that the changing climatic conditions (warmed seawater) caused a reduction of the wood-destroying sea creatures in the warmed seawater. In addition, the 
test period of seven months may not have given sufficient time for other species to settle in the wood.

Figure 3 shows the destruction evaluation of test panels after cutting, and the nondestructive assessment by X-ray before cutting. After inspection, all samples were found to have been attacked by $T$. navalis. Especially serious damage was shown in the samples exposed at the test sites of Trabzon and Samsun. The samples from Trabzon were breakable by hand. The tunnels created by $T$. navalis in the samples from Trabzon and Samsun were too numerous to count and covered more than $50 \%$ of the surface. Further study is needed to examine the resistance of novel wood preservatives, nanobiocides, and non-biocidal treatments to marine borers as well as to assess these treatments with non-destructive techniques such as ultrasonic and acoustic methods.

\section{ICP Analysis of Wood Samples}

The macro- and microelement results of the test and the control samples are given in Tables 1 and 2. The samples were subjected to ICP analysis to determine how these elements affected the life of the marine organisms in the three test regions.

The $\mathrm{pH}$ values of seawater that the wood samples were exposed to had varied (Table 1). Two- to three-point differences were observed in the test samples compared to the control. The change in $\mathrm{pH}$ values is an indicator of biological degradation by various microorganisms (wood-degrading bacteria, erosion bacteria, tunneling bacteria, and softrot fungi) (Björdal 2012; Fojutowski et al. 2014). Teredo navalis attacks wooden structures as a pediveliger larva. The soft-shelled larva penetrates the wood in an undetermined manner with maternal enzymes playing a role in softening the surface. The $T$. navalis eats its way into the wood and digests it with the help of endosymbiotic bacteria (Hoppe 2002).

Table 1. Macroelements ( $\mathrm{Na}, \mathrm{Mg}, \mathrm{P}, \mathrm{S}, \mathrm{Cl}, \mathrm{K}$, and $\mathrm{Ca}$ ) in Samples of Scots Pine Submerged for 7 Months in Seawater at Different Locations in Turkey

\begin{tabular}{|c|c|c|c|c|c|c|c|c|c|}
\hline \multirow{2}{*}{} & \multirow{2}{*}{$\mathrm{pH}$} & $\mathrm{N}$ & $\mathrm{Mg}$ & $\mathrm{P}$ & $\mathrm{S}$ & $\mathrm{Cl}$ & $\mathrm{K}$ & $\mathrm{Ca}$ \\
\cline { 3 - 9 } & & \multicolumn{7}{|c|}{ Wood Dry Mass $(\mathrm{mg} / \mathrm{kg})$} \\
\hline Control & 5.84 & 100 & 3570 & 40 & 70 & 60 & 430 & 1500 \\
\hline Trabzon & 8.04 & $1.2 \mathrm{E}+07$ & $1.1 \mathrm{E}+07$ & 860 & 2950 & $3 \mathrm{E}+07$ & 2310 & $1 \mathrm{E}+08$ \\
\hline Samsun & 7.92 & 5780 & 9290 & 750 & 3040 & $1 \mathrm{E}+07$ & 1980 & $3.3 \mathrm{E}+07$ \\
\hline Zonguldak & 8.43 & 7760 & 6280 & 180 & 3780 & $2 \mathrm{E}+07$ & 1380 & $2.2 \mathrm{E}+07$ \\
\hline
\end{tabular}

Table 2. Microelements ( $\mathrm{Mn}, \mathrm{Fe}, \mathrm{Cu}, \mathrm{Zn}, \mathrm{Cd}, \mathrm{Al}$, and $\mathrm{Pb}$ ) in Samples of Scots Pine Submerged for 7 Months in Seawater at Different Locations in Turkey

\begin{tabular}{|c|c|c|c|c|c|c|c|c|}
\hline & Al & Mn & Fe & Cu & Zn & Cd & Pb \\
\cline { 2 - 8 } & \multicolumn{7}{|c|}{ Wood Dry Mass $(\mathrm{mg} / \mathrm{kg})$} \\
\hline Control & 1.5 & 50.0 & 9.0 & 30.0 & 2,0 & 70.0 & 3.7 \\
\hline Trabzon & 6.1 & 100.0 & 2400.0 & 80.0 & 18.1 & 20.7 & 132.6 \\
\hline Samsun & 5.7 & 345.0 & 2260.0 & 18.6 & 20.2 & 91.6 & 20.2 \\
\hline Zonguldak & 0.6 & 568.0 & 3450.0 & 15.0 & 22.2 & 271.5 & 41.8 \\
\hline
\end{tabular}

The elements content of Scots pine wood samples increased after seven months of exposure to seawater in Trabzon, Samsun, and Zonguldak. This can be explained by the differences of mineral content of the water in the test sites. Macro- and microelement contents increased as shown in the present study (Tables 1 and 2). The $\mathrm{N}, \mathrm{Mg}, \mathrm{S}, \mathrm{Cl}, \mathrm{Ca}$, 
$\mathrm{Fe}, \mathrm{Zn}$, and $\mathrm{Pb}$ content increased considerably in the samples after exposure to seawater, whereas the $\mathrm{P}, \mathrm{K}, \mathrm{Al}, \mathrm{Mn}, \mathrm{Cu}$, and $\mathrm{Cd}$ showed small increases. The increasing amount of elements is important for the survival of T. navalis as the presence of these minerals help the species break down the cellulose in the wood and use it as a nutrient. The first destruction of $T$. navalis on wood is caused by mechanical means, followed by the digestion of the wood with enzymes secreted by symbiotic bacteria. These bacteria are not only able to digest cellulose, but they also fix molecular nitrogen, something that is lacking in wood and is needed for normal animal metabolism (Waterbury et al. 1983; Distel et al. 1991). Therefore, the amount of nitrogen in all samples increased noticeable (by about $99 \%$ ). It was possibly attributed to the metabolism of the borers. However, the difference in water quality could also be the cause. The high iron content in the samples caused the samples to change color (Borges et al. 2003). According to the X-ray results, the severity of the damage seemed higher in Trabzon. The values of Mn, Fe, Zn, and $\mathrm{Cd}$ in the Zonguldak samples were higher than in the samples from the Trabzon and Samsun regions.

\section{FTIR Analysis}

The region of 1800 to $700 \mathrm{~cm}^{-1}$ included the main functional groups for organic material, which were characterized for cellulose, hemicellulose, and lignin (Liu et al. 2018). It was clear that exposure to the seawater caused notable changes in the wood chemical structure of the specimens (Figs. 4 and 5).

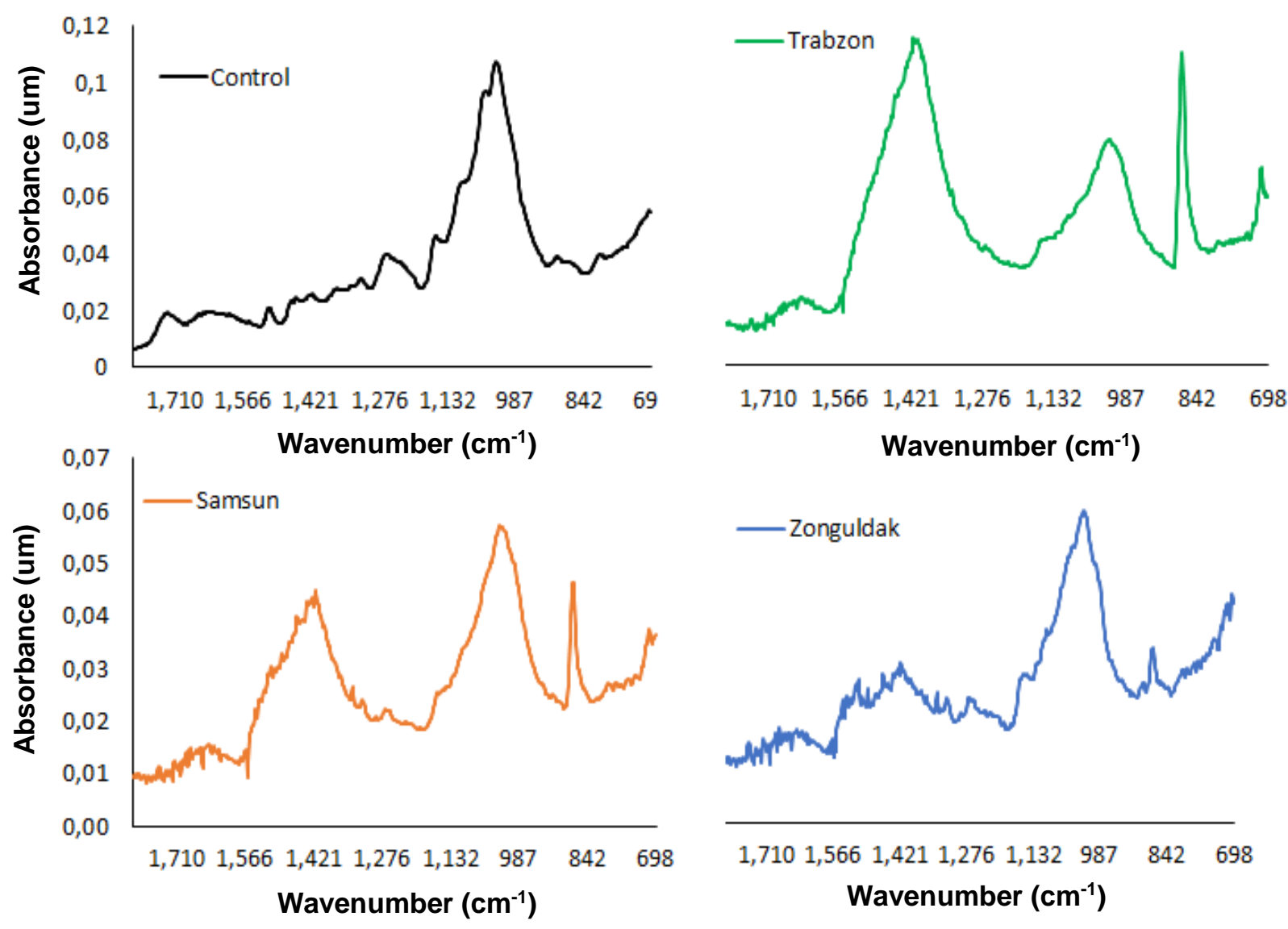

Fig. 4. The FTIR analysis results of samples exposed to 7-month marine environment 


\section{Lignin and Carbohydrate by FTIR-ATR}

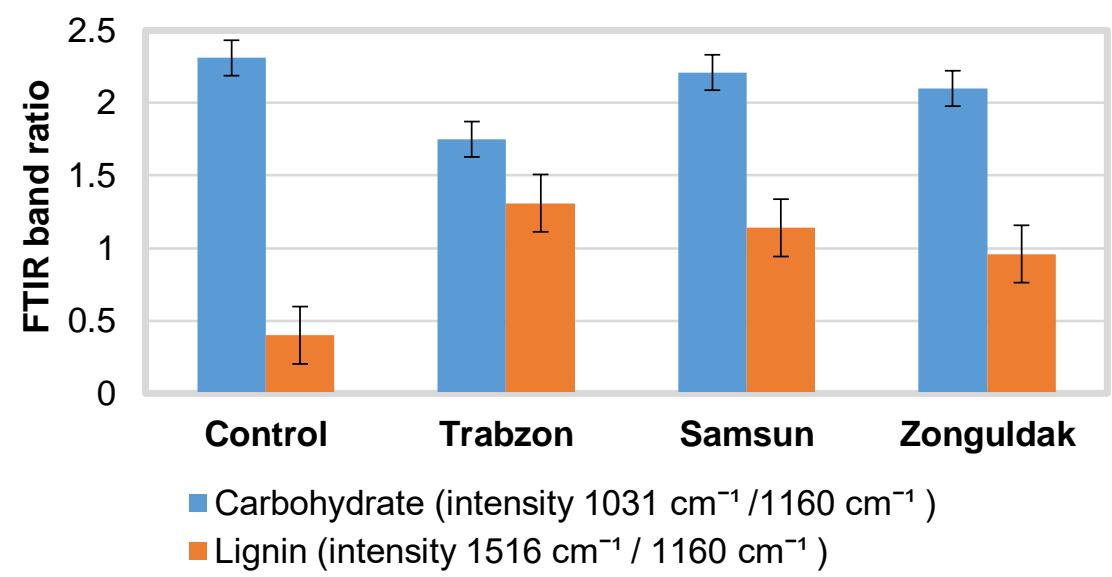

Fig. 5. Lignin and carbohydrate ratios in wood samples determined by ATR-FTIR spectroscopy

The most remarkable change in the wood samples was the peak at $1408 \mathrm{~cm}^{-1}$. The highest increase in peak intensity was observed in the samples from the Trabzon region. No change was observed in the samples from the Zonguldak region. These structural differences in the wood samples are also supported by Fig. 3 results. The damage caused by $T$. navalis in the Trabzon samples was higher compared to the samples from other regions (Fig. 3). Peaks between 1340 and $1410 \mathrm{~cm}^{-1}$ show nitrate (NO-3) bonds (Thomas 2019). According to the results obtained from the ICP study, it seemed that the nitrogen had increased. In addition, the increase in the amount of nitrogen reported in the wood samples exposed to seawater was due to the increase of nitrate and ammonia. Moreover, $T$. navalis fixed the amount of needed nitrogen that was missing in the wood. According to Borges and Cragg et al. (2003), the nitrogen value of $0.17 \%$ in control samples compared to dry weight increased to $0.86 \%$ in samples exposed to seawater; these peaks showed the $\mathrm{C}-\mathrm{H}$ deformation in lignin and carbohydrates content in the wood (Faix 1991). The lignin content of samples from Trabzon and Samsun appeared to have remarkable increased (Figs. 4 and 5).

The 1020 and $1040 \mathrm{~cm}^{-1}$ peaks were associated with modification of cellulose and hemicelluloses. The $\mathrm{C}-\mathrm{H}$ bond found in cellulose, hemicelluloses, and the $\mathrm{C}=\mathrm{O}$ bond, and cellulose present in lignin express the $\mathrm{C}-\mathrm{O}$ bonds in hemicelluloses. The relationship of these peaks with polysaccharides has been reported in the literature (Can and Sivrikaya 2019). There was a remarkable reduction in these peak. There was a decrease in all regions. At the wavelength of $869 \mathrm{~cm}^{-1}, \mathrm{C}-\mathrm{H}$ deformation peaks were seen in cellulose. The 869 $\mathrm{cm}^{-1}$ peaks also showed a $-\mathrm{CH}_{2}$ rocking vibration in the $\mathrm{Si}-\mathrm{CH}_{3}$ moiety. In this study, the maximum increase was observed in the $869 \mathrm{~cm}^{-1}$ peaks of the Trabzon samples, which were the most damaged according to the X-ray results. There were also remarkable increases in the Samsun samples.

The peaks of $710 \mathrm{~cm}^{-1}$ shown in Fig. 4 refer to the $-\mathrm{CH}_{2}$ rocking vibrations in the crystalline region of the cellulose (Abidi et al. 2014). The strong methylene bonds exhibited a long-chain linear aliphatic structure (Lesar et al. 2011). This peak value showed increases in the Trabzon and Samsun samples. These increases indicated that the 
amorphous region had disintegrated and more of the crystal region had remained in the wood samples.

The cellulose, hemicellulose, and lignin in the structure were observed to decrease after biological degradation, resulting in the loss of weight of the wood samples. Living inside timber as it does, Teredo navalis is protected from predators. Unlike other boring bivalves, T. navalis feeds almost exclusively on wood (sugar molecules in the cellulose) (Waterbury et al. 1983). In this study, the lowest carbohydrate ratio was obtained in the Trabzon samples and the highest was in the control samples. The low carbohydrate content in the Trabzon samples meant that the destruction was high. T. navalis harbours symbiotic microorganisms that produce the carbohydrate that enables them to digest cellulose from the wood they bore into (Morton 1970).

\section{CONCLUSIONS}

1. Teredo navalis was the single species identified in all test sites, whereas previous authors had reported different borers in the Black Sea regions. The Scots pine panels were heavily attacked by $T$. navalis in all test sites after seven months. This finding indicated there is great threat posed to maritime structures in the Black Sea by these marine borers.

2. The increase in mineral content was attributed to the different seawater qualities for the three regions. Additionally, increased mineral content of wood was attributed to the borers' activity.

3. The $\mathrm{pH}$ values in the wood panels increased after the marine trial. Carbohydrate ratios decreased, while lignin ratios increased.

\section{ACKNOWLEDGMENTS}

This study received no specific grant from funding agencies in the public, commercial, or non-profit sectors.

\section{REFERENCES CITED}

Abidi, N., Cabrales, L., and Haigler, C. H. (2014). "Changes in the cell wall and cellulose content of developing cotton fibers investigated by FTIR spectroscopy," Carbohydrate Polymers 100, 9-16. DOI: 10.1016/j.carbpol.2013.01.074

AWPA A7 (1993). "Standard for wet ashing procedures for preparing wood for chemical analysis," American Wood Protection Association, Birmingham, AL, USA.

Bergman, R., Puettmann, M., Taylor, A., and Skog, K. E. (2014). "The carbon impacts of wood products," Forest Products Journal 64(7-8), 220-231. DOI: 10.13073/FPJ-D14-00047

Björdal, C. G. (2012). "Microbial degradation of waterlogged archaeological wood," Journal of Cultural Heritage 13(3), S118-S122. DOI: 10.1016/j.culher.2012.02.003 
Bobat, A. (1994). Use and Service Life of Preservative Treated Wood Material in Underground Coal Mines and in Sea Water, Ph.D. Thesis, Karadeniz Technical University, Graduate School of Natural and Applied Sciences, Trabzon, Turkey.

Borges, L. M. S., Cragg, S. M., and Williams, J. R. (2003). "Comparing the resistance of a number of lesser known species of tropical hardwoods to the marine borer Limnoria using a short term laboratory assay (IRG/WP 03-10500)," in: The International Research Group on Wood Preservation, Brisbane, Australia.

Borges, L. M. S., Merckelbach, L. M., Sampaio, Í., and Cragg, S. M. (2014). 'Diversity, environmental requirements, and biogeography of bivalve wood-borers (Teredinidae) in European coastal waters," Frontiers in Zoology 11(1), 1-13.

Borges, L. M. S. (2014). "Biodegradation of wood exposed in the marine environment: Evaluation of the hazard posed by marine wood-borers in fifteen European sites," International Biodeterioration \& Biodegradation 96, 97-104. DOI: 10.1016/j.ibiod.2014.10.003

Can, A., and Sivrikaya, H. (2019). "Surface characterization of wood treated with boron compounds combined with water repellents," Color Research and Application 44(3), 462-472. DOI: $10.1002 /$ col.22357

Cragg, S. M. (1996). "Timber in the marine environment," Timber Trades J. 376, 26-28.

Cragg, S. M., Pitman, A. J., and Henderson, S. M. (1999). "Developments in the understanding of the biology of marine wood boring crustaceans and in methods of controlling them," International Biodeterioration \& Biodegradation 43(4), 197-205. DOI: 10.1016/S0964-8305(99)00054-2

Distel, D. L., DeLong, E. F., and Waterbury, J. B. (1991). "Phylogenetic characterization and in situ localization of the bacterial symbiont of shipworms (Teredinidae: Bivalvia) by using $16 \mathrm{~S}$ rRNA sequence analysis and oligodeoxynucleotide probe hybridization," Applied and Environmental Microbiology 57(8), 2376-2382.

Eriksen, A. M., Gregory, D. J., and Botfeldt, K. (2014). "The survival of Teredo navalis L. in timber wrapped in TERRAM4000 and a plastic membrane," International Biodeterioration \& Biodegradation 86(B), 96-101. DOI: 10.1016/j.ibiod.2013.06.021

Faix, O. (1991). "Classification of lignins from different botanical origins by FTIR spectroscopy," Holzforschung 45(S1), 21-27. DOI: 10.1515/hfsg.1991.45.s1.21

Fojutowski, A., Wróblewska, H., Komorowicz, M., Kropacz, A., Noskowiak, A., and Pomian, I. (2014). "Changes in the properties of English oak wood (Quercus robur L.) as a result of remaining submerged in Baltic Sea waters for two years," International Biodeterioration \& Biodegradation 86(B), 122-128. DOI: 10.1016/j.ibiod.2013.06.029

Hoppe, K. (2002). "Teredo navalis - The cryptogenic shipworm," in: Invasive Aquatic Species of Europe. Distribution, Impacts and Management, E. Leppäkoski, S. Gollasch, and S. Olenin, (eds.), Kluwer Academic Publishers, The Netherlands.

Lesar, B., Pavlič, M., Petrič, M., Škapin, A. S., and Humar, M. (2011). "Wax treatment of wood slows photodegradation," Polymer Degradation and Stabililty 96(7), 12711278. DOI: 10.1016/j.polymdegradstab.2011.04.006

Liu, M., Zhong, H., Ma, E., and Liu, R. (2018). "Resistance to fungal decay of paraffin wax emulsion/copper azole compound system treated wood," International Biodeterioration \& Biodegradation 129, 61-66. DOI: 10.1016/j.ibiod.2018.01.005 Morton, B. (1970). "The functional anatomy of the organs of feeding and digestion of Teredo navalis Linnaeus and Lyrodus pedicellatus (Quatrefages)". Journal of 
Molluscan Studies 29 (2-3), 151-167. DOI: 10.1093/oxfordjournals.mollus.a065089

Muhiddin, C., Etemoğlu, A. B., and Atakan, A. (2002). "Technical and economical analysis of desalination processes," Uludağ University Journal of Engineering and Architecture 7(1), 147-160.

Perçin, O. (2007). The Effect of Sea Water to Laminated Wooden Material, Master's Thesis, Dumlupınar University, Inst. of Science and Technology, Kütahya, Turkey.

Pınar, E. (1997). Fouling and Boring Organisms in Turkey Liman, Antifouling Antiboring of These Organisms on Paint Activity, Second edition, DKK Hydrographic Publications, Çubuklu-İstanbul, Turkey.

Sen, S., Sivrikaya, H., Yalcin, M., Bakir, A. K., and Ozturk, B. (2010). 'Fouling and boring organisms that deteriorate various European and tropical woods at Turkish seas," African Journal of Biotechnology 9(17), 2566-2573.

Sivrikaya, H., Cragg, S., and Borges, L. (2008). "Variation of commercial timbers from Turkey in resistance to marine borers as assessed by marine trial and laboratory screening (IRG/WP 08-10668)," in: International Research Group on Wood Preservation, Istanbul, Turkey.

Sivrikaya, H., Çetin, H., Tümen, İ., Temiz, C., and Borges, L. M. S. (2016). "Performance of copper azole treated softwoods exposed to marine borers," Maderas. Ciencia y Tecnologia 18(2), 349-360. DOI: 10.4067/S0718-221X2016005000032

Sivrikaya, H., Hafizoglu, H., Cragg, S. M., Carrillo, A., Militz, H., Mai, C., and Borges, L. M. S. (2012). "Evaluation of wooden materials deteriorated by marine-wood boring organisms in the Black Sea," Maderas. Ciencia y Tecnologia 14(1), 79-90. DOI: $10.4067 / \mathrm{s} 0718-221 \times 2012000100007$

Sivrikaya, H., Cragg, S. M., and Borges, L. M. (2009). "Variation in resistance to marine borers in commercial timbers from Turkey, as assessed by marine trial and laboratory screening," Turkish Journal of Agriculture and Forestry 33(6), 569-576. DOI: 10.3906/tar-0902-28

TAPPI Tm-45 (1992). “TAPPI test methods 1992-1993,” TAPPI Press, Atlanta, GA. Thomas, S. (2019). "Spectroscopic tools," (http://www.science-and-fun.de/tools/), Accessed 22 May 2019.

TS EN 275 (2000). "Wood preservatives. Determination of the protective effectiveness against marine borers," European Committee for Standardization, Brussels, Belgium.

Turner, R. D. (1966). A Survey and Illustrated Catalogue of the Teredinidae, Museum of Comparative Zoology, Harvard University, Cambridge, MA, USA.

Turner, R. D. (1971). “Australian shipworms," Australian Nat. History 17(4), 139-145.

Waterbury, J. B., Calloway, C. B., and Turner, R. D. (1983). “A cellulolytic nitrogenfixing bacterium cultured from the gland of Deshayes in shipworms (Bivalvia: Teredinidae)," Science 221(4618), 1401-1403. DOI: 10.1126/science.221.4618.1401

Williams, J. R., Sawyer, G. S., Cragg, S. M, and Simm, J. (2005). "A questionnaire survey to establish the perceptions of UK specifiers concerning the key material attributes of timber for use in marine and fresh water engineering," Journal of Institute of Wood Science 17(1), 41-50. DOI: 10.1179/wsc.2005.17.1.41

Article submitted: September 26, 2019; Peer review completed: December 8, 2019; Revised version received: December 10, 2019; Accepted: April 16, 2020; Published: April 20, 2020.

DOI: $10.15376 /$ biores.15.2.4271-4281 